\title{
KEPUASAN FINANSIAL PADA INDIVIDU MENIKAH DI KOTA SURABAYA
}

\author{
Avikhatus Sholihah \\ Universitas Negeri Surabaya \\ Avikhatus.17080574044@mhs.unesa.ac.id
}

\begin{abstract}
Married people have more needs than unmarried people, so they must manage their finances properly to achieve financial satisfaction. If married people can not manage their finance, they will felt dissatisfied with their financial condition. This situation can lead them to divorce by the economic problem. For this reason, this study aims to examine the factors that increase financial satisfaction in married people. Personal income, financial literacy, financial attitude, and financial management behavior will be examined in this study. A total of 110 married people in Surabaya with personal income and age range from 25-65 years were made into a sample in this study. This study uses multiple linear regression by using SPSS 25 program. This study found that personal income, financial attitude, and financial management behavior significantly affect financial satisfaction. While financial literacy does not affect financial satisfaction.
\end{abstract}

Keywords: personal income; financial attitude; financial literacy; financial management behavior; financial satisfaction.

\section{PENDAHULUAN}

Aspek keuangan menjadi faktor penting untuk memenuhi kebutuhan saat ini maupun kebutuhan masa depan. Diperlukan kemampuan mengelola keuangan yang baik terutama bagi individu yang sudah menikah agar tidak terjadi permasalahan keuangan dalam keluarga. Karena jika permasalahan keuangan ini tidak dikelola dengan baik, maka dapat menyebabkan perceraian (Yap, et al., 2016). Berdasarkan data BPS.go.id (2020), kasus perceraian di Indonesia cukup tinggi dan meningkat setiap tahunnya. Tahun 2015 terdapat 353.843 kasus, tahun 2016 terdapat 365.654 kasus, tahun 2017 terdapat 374.516 kasus, tahun 2018 terdapat 408.2020 kasus, dan tahun 2019 terdapat 439.002 kasus. Kemudian, provinsi Jawa Barat, Kota Semarang, dan Kota Surabaya merupakan daerah dengan jumlah perceraian terbanyak ada di Pulau Jawa (Firmansyah, 2020).

Tahun 2018 tercatat penyebab perceraian di Jawa Timur yaitu pertengkaran sebesar 44\%, faktor ekonomi sebesar 37\%, dan KDRT, zina, mabuk, kawin paksa, judi, cacat fisik, meninggalkan, pindah agama, poligami, dan lainnya (Jatim.bps.go.id, 2019). Perceraian akibat faktor ekonomi menunjukkan adanya ketidakpuasan atas kondisi keuangan dalam keluarga atau bahkan adanya masalah finansial. Puas atau tidaknya individu yang sudah menikah atas kondisi keuangannya berdasarkan pada persepsi dan evaluasi individu itu sendiri. Oleh karena itu, individu dengan kondisi keuangan yang sama bisa jadi memiliki tingkat kepuasan finansial yang berbeda (Rutherford dan Fox, 2010). Konsep penentu kepuasan finansial dan pemahaman tentang faktor-faktor yang memengaruhi kepuasan finansial diperlukan oleh keluarga, karena dengan itu keluarga dapat memanfaatkan cara yang lebih efisien untuk meningkatkan kualitas hidup (Joo, 2008). Diener et al. (1999) juga menyatakan financial satisfaction merupakan subbagian dari kesejahteraan hidup secara umum. Untuk itu, penting bagi individu yang sudah menikah supaya mengelola keuangannya dengan baik guna mencapai kepuasan finansial. Pada saat ini, bukan hanya suami saja yang bekerja dan mendapatkan pendapatan untuk memenuhi kebutuhan keluarga, namun sekarang banyak juga istri yang bekerja. Berdasarkan BPS.go.id (2020), tercatat bahwa jumlah pekerja perempuan meningkat setiap tahunnya, pada bulan Februari 2020 pekerja perempuan mencapai 51.934 .989 pekerja. Oleh karena itu, baik suami maupun istri bertanggung jawab atas pengelolaan keuangan keluarga.

Dari uraian di atas, individu yang sudah menikah di Kota Surabaya dipilih sebagai objek dalam penelitian ini. Variabel yang akan diteliti untuk mengukur tingkat kepuasan finansial individu yang sudah menikah di Kota Surabaya yaitu variabel personal income, financial attitude, financial literacy, dan financial management behavior. Variabel personal income akan disebut sebagai pendapatan 
pribadi, financial attitude sebagai sikap keuangan, financial literacy sebagai literasi keuangan, dan financial management behavior sebagai perilaku keuangan. Pendapatan pribadi adalah sejumlah uang dari berbagai sumber seperti gaji pekerjaan, keuntungan dari bisnis yang dijalankan, maupun sumbersumber lainnya atau bahkan tanpa melakukan apapun (Coşkuner, 2016). Individu dengan pendapatan pribadi yang lebih tinggi lebih memungkinkan individu tersebut untuk merasa puas dengan situasi dan kondisi keuangan mereka secara keseluruhan. Aboagye dan Jung (2018), Ferrer dan Gërxhani (2011), dan Hakim et al. (2014) mengatakan besarnya pendapatan pribadi berpengaruh terhadap kepuasan finansial yang dirasakan individu. Berlawanan dengan itu, Rusdini et al. (2020) menyatakan pendapatan pribadi tidak berpengaruh terhadap kepuasan finansial.

Literasi keuangan adalah life skill yang meliputi pemahaman dan keterampilan keuangan individu untuk merencanakan dan mengelola keuangan dengan baik yang pada akhirnya kesejahteraan individu akan tercapai (Ojk.go.id, 2017). Halim dan Astuti (2015) menyatakan literasi keuangan sebagai kemampuan untuk mengambil keputusan yang tepat di bidang keuangan agar tidak terjadi masalah keuangan. Literasi keuangan memiliki pengaruh yang signifikan terhadap kepuasan finansial (Robb et al. 2019), (Arifin, 2018), dan (Falahati, Sabri, \& Paim, 2012). Berbeda dengan Yap et al. (2016) dan Ali et al. (2013), yang menyatakan kepuasan finansial tidak dipengaruhi oleh literasi keuangan.

Berkaitan dengan sikap keuangan, Ajzen (2005) menjelaskan sikap adalah derajat evaluasi atas apa yang disukai atau tidak disukai dari perilaku. Dalam hal ini sikap keuangan merupakan penilaian individu akan baik dan buruknya perilaku yang berkaitan dengan keuangan. Setiyani dan Solichatun (2019) menyatakan sikap keuangan berkontribusi dalam menentukan keputusan setiap harinya, sehingga sikap keuangan memiliki pengaruh penting dalam kepuasan finansial. Serupa dengan Falahati et al. (2012), Aboagye dan Jung (2018), dan Hakim et al. (2014) menyatakan sikap keuangan berpengaruh terhadap kepuasan finansial. Sedangkan pernyataan sebaliknya dikemukakan oleh Yap et al. (2016), kepuasan keuangan individu tidak dipengaruhi oleh sikap keuangan.

Perilaku keuangan adalah usaha individu dalam meningkatkan kebahagiaan dan kesejahteraan hidupnya (Parmitasari, 2018). Artinya, perilaku keuangan bukanlah sebuah hasil akhir melainkan sebuah kontribusi untuk mencapai hasil akhir yaitu kepuasan finansial. Oleh karena itu, setiap individu harus memiliki perilaku keuangan yang baik untuk mencapai kepuasan finansial. Xiao et al. (2014), Parmitasari (2018), Aboagye dan Jung (2018) menyatakan adanya pengaruh positif antara perilaku keuangan terhadap kepuasan finansial.

Berdasarkan pemaparan fenomena dan riset gap di atas, maka tujuan dari penelitian ini adalah menguji ada atau tidaknya pengaruh antara variabel pendapatan pribadi, literasi keuangan, sikap keuangan, dan perilaku keuangan terhadap kepuasan finansial pada individu yang sudah menikah di Kota Surabaya.

\section{KAJIAN PUSTAKA DAN PENGEMBANGAN HIPOTESIS}

\section{Teori Subjective Well Being (SWB)}

Subjective well being menjelaskan reaksi emosional individu, faktor-faktor kepuasan, dan penilaian kepuasan hidup berdasar pada sudut pandang masing-masing individu (Diener et al. 1999). Teori ini menggambarkan reaksi emosi pada individu yang timbul atas suatu hal yang terjadi atau ketika individu menilai kepuasan hidupnya secara keseluruhan. Penilaian individu akan kepuasan hidup meliputi berbagai perasaan bahagia atau sedih atas peristiwa hidup, dan rasa puas yang dirasakan individu seperti puas akan kondisi kesehatannya, pendapatannya, dan lain-lain (Diener et al., 1999). Tingkat kepuasan hidup setiap individu dapat dinilai secara subjektif oleh masing-masing individu itu sendiri. Dengan demikian individu dengan latar belakang dan kondisi yang sama dimungkinkan akan memiliki tingkat kepuasan yang berbeda (Rutherford dan Fox, 2010).

Diener et al. (1999) menyatakan Subjective Well-Being (SWB) menilai dan mengevaluasi kondisi dan situasi kehidupan individu atas peristiwa hidup yang menyenangkan maupun peristiwa hidup yang tidak menyenangkan. Individu yang mengalami peristiwa hidup positif dan menyenangkan akan 
merasa hidup mereka lebih berharga dan bahagia. Dengan begitu, dapat dikatakan bahwa individu telah mencapai kepuasan.

\section{Teori Theory of Planned Behavior (TPB)}

Theory of planned behavior menjelaskan proses terbentuknya sebuah perilaku dalam konteks tertentu (Azjen, 1991). Azjen (1991) menjelaskan bahwa sikap, kontrol perilaku, dan norma subjektif merupakan tiga hal penting yang melatarbelakangi perilaku individu. Lebih lanjut, theory of planned behavior yang dikemukakan oleh Azjen (1991) menjelaskan pengertian dari sikap, kontrol perilaku, dan norma subjektif. Sikap dalam teori ini dijelaskan sebagai sikap yang mengacu pada penilaian atas sebuah perilaku, apakah akan mendatangkan kebaikan atau tidak jika perilaku tersebut dilakukan. Sedangkan norma subjektif adalah faktor sosial yang memengaruhi dilakukan atau tidak dilakukannya sebuah perilaku akibat tekanan sosial yang dirasakan individu, di mana tekanan sosial tersebut bisa bersumber dari orang-orang terdekat. Kontrol perilaku merupakan berbagai kemudahan dan kesulitan yang dialami individu ketika melakukan suatu perilaku.

\section{Pendapatan Pribadi}

Pendapatan pribadi adalah sejumlah uang dari berbagai sumber seperti gaji pekerjaan, keuntungan dari bisnis yang dijalankan, maupun sumber-sumber lainnya atau bahkan tanpa melakukan apapun (Coşkuner, 2016). Pendapatan merupakan hal terpenting dalam pengelolaan keuangan dan pemenuhan kebutuhan. Dalam masyarakat modern, keuangan menjadi domain penting dalam kehidupan (Xiao et al., 2014). Seberapa tinggi pendapatan individu akan ditanyakan dengan menggunakan skala ordinal 1 sampai 4 yang digunakan juga oleh Aboagye dan Jung (2018), yang mana semakin tinggi skornya menunjukkan semakin tinggi pendapatannya. Skor 1 menunjukkan pendapatan $\leq 4.200 .000$, skor 2 menunjukkan pendapatan $>4.200 .000$ sampai $\leq 7.200 .000$, skor 3 menunjukkan pendapatan $>7.200 .0000$ sampai $\leq 10.200 .000$, dan skor 4 menunjukkan pendapatan $>10.200 .000$

\section{Literasi Keuangan}

Literasi keuangan diartikan sebagai kecerdasan individu dalam menggunakan uang yang didasari oleh pengetahuan individu, fakta, konsep, prinsip, dan teknologi yang mendasari untuk cerdas dalam menggunakan uang (Garman dan Forgue, 2011). Literasi keuangan diukur dengan empat indikator yang diambil dari Chen dan Volpe (1998) yaitu keuangan pribadi, tabungan, asuransi, dan investasi.

\section{Sikap Keuangan}

Sikap dan cara berpikir individu di bidang keuangan diartikan sebagai sikap keuangan (Arifin, 2018). Sikap keuangan mempunyai pengaruh penting dalam kepuasan finansial karena keputusan yang diambil dalam kehidupan sehar-hari khususnya dibidang keuangan akan ditentukan oleh sikap keuangan (Setiyani dan Solichatun, 2019). Sikap keuangan diukur dengan enam indikator yang diambil dari Furnham (1984), yaitu security (keamanan), retention (penyimpanan), inadequacy (ketidakpuasan), the effort (upaya), the power (kekuatan), dan obsession (obsesi).

\section{Perilaku Keuangan}

Perilaku keuangan menunjukkan seberapa baik perilaku keuangan individu yang meliputi pengelolaan sumber daya keuangan seperti perencanaan anggaran tabungan, asuransi, dan investasi bagi suatu rumah tangga (Hasibuan, et al., 2018). Perilaku keuangan adalah upaya yang dilakukan untuk mencapai tujuan keuangan, sehingga individu akan mencapai kepuasan keuangan yang diinginkan (Parmitasari, 2018). Untuk mengukur seberapa baik perilaku keuangan individu, Arifin (2018) menggunakan beberapa indikator yaitu: pengeluaran, membayar tagihan, perencanaan keuangan, menyediakan uang untuk diri sendiri dan keluarga, dan tabungan.

\section{Kepuasan Finansial}

Kepuasan finansial adalah ukuran kepuasan individu atas situasi keuangan mereka berdasarkan sudut pandang masing-masing individu (Ferrer dan Gërxhani, 2011). Ferrer dan Gërxhani (2011) juga menyatakan sudut pandang individu dalam melihat kepuasan finansial biasanya tergantung pada perbandingan situasi keuangan mereka saat ini dengan masa lalu, dengan individu lain dalam 
masyarakat, dan dengan apa yang diharapkan individu di masa depan. Untuk mengukur seberapa puas individu atas kondisi keuangannya, Hasibuan et al. (2018) menggunakan enam indikator diantaranya menetapkan tujuan hidupnya, pandangan individu terhadap pendapatannya, mempunyai pinjaman atau tidak, tabungan, memastikan ketersediaan uang di masa depan, dan mengatur masalah keuanganya, serta memenuhi kebutuhan dasarnya.

\section{Hubungan antar Variabel}

Pendapatan pribadi menjadi hal penting dan utama dalam kehidupan individu saat ini. Xiao et al. (2014) menyatakan keuangan menjadi domain penting dalam kehidupan. Pentingnya pendapatan pribadi dalam kehidupan individu terlihat dari keterkaitan pendapatan pribadi terhadap kepuasan finansial yang dirasakan individu. Keterkaitan ini dijelaskan oleh Diener et al. (1999) dalam teori subjective well being, kepuasan akan dirasakan individu ketika individu tersebut mengalami peristiwa positif yang menyenangkan. Ketika pendapatan individu tinggi, maka berbagai kebutuhan akan lebih mudah untuk dipenuhi, di mana mampu memenuhi kebutuhan merupakan peristiwa positif yang menyenangkan dan menuntun individu ke kepuasan finansial. Seperti yang dikatakan oleh Arifin (2018) kepuasan finansial berasal dari perilaku individu dalam mengelola pendapatannya guna memenuhi kebutuhan finansial, yang mana kebutuhan finansial dapat dikatakan berhasil salah satunya yaitu ketika individu dapat memenuhi kebutuhan dasarnya. Diener et al. (1999) menjelaskan bahwa tingginya pendapatan akan meningkatkan kepuasan finansial. Serupa dengan Aboagye dan Jung (2018), Sawitri (2018), dan Hasibuan et al. (2018) menyatakan bahwa pendapatan pribadi berpengaruh positif terhadap financial satisfaction, semakin tinggi pendapatan inidvidu akan meningkatkan kepuasan finansial individu tersebut.

H1 : Pendapatan pribadi berpengaruh signifikan terhadap kepuasan finansial pada individu yang sudah menikah di Kota Surabaya.

Theory of planned behavior, informasi merupakan salah satu faktor yang melatarbelakangi perilaku manusia (Ajzen, 2005). Literasi keuangan termasuk dalam informasi yang berkaitan dengan pengetahuan dan pemahaman individu mengenai keuangan. Halim dan Astuti (2015) mendefinisikan literasi keuangan sebagai kemampuan memahami, menganalisis dan mengelola informasi keuangan untuk mengambil keputusan keuangan. Literasi keuangan yang baik akan membantu individu dalam menentukan keputusan yang akurat, mengelola keuangan dengan bijak, dan perilaku keuangan yang baik, di mana hal ini akan membantu dalam memeroleh kepuasan finansial (Hasibuan et al., 2018). Falahati et al. (2012), Setiyani dan Solichatun (2019), dan Xiao et al. (2014) menyatakan adanya pengaruh signifikan antara literasi keuangan terhadap kepuasan finansial.

H2 : Literasi keuangan berpengaruh signifikan terhadap kepuasan finansial pada individu yang sudah menikah di Kota Surabaya.

Sikap keuangan termasuk ke dalam attitude towards behavior yang diartikan sebagai penilaian yang dilakukan individu terhadap baik atau buruknya suatu perilaku (Ajzen, 2005). Sikap keuangan sangat penting bagi tercapainya kepuasan finansial, karena keputusan keuangan yang diambil oleh individu setiap harinya ditentukan oleh sikap keuangan individu (Setiyani dan Solichatun, 2019). Ketika individu yang menganggap uang sebagai sesuatu yang berharga dan harus dipertanggungjawabkan, maka sikap tersebut akan mendorong individu untuk memiliki keuangan yang sehat (adanya tabungan, investasi, asuransi, dan lain-lain) yang pada akhirnya akan meningkatkan kualitas hidup dan juga meningkatkan kepuasan finansial (Arifin, 2018). Robb et al. (2019), Arifin (2018), Setiyani dan Solichatun (2019), dan Falahati et al. (2012) mengatakan adanya pengaruh positif antara sikap keuangan terhadap kepuasan keuangan.

H3 : Sikap keuangan berpengaruh signifikan terhadap kepuasan finansial pada individu yang sudah menikah di Kota Surabaya.

Theory of planned behavior yang dikemukakan oleh Azjen (1991), menjelaskan bahwa individu berperilaku berdasarkan dari informasi atau keyakinan yang relevan dengan perilaku tersebut. 
Keyakinan individu tentang hasil yang akan diperoleh ketika melakukan suatu perilaku tertentu dianggap sebagai penentu dari niat dan tidakan individu (Arifin, 2018). Keyakinan yang baik atas perilaku tertentu, membuat individu melakukan suatu perencanaan untuk mencapai perilaku tersebut. Ketika suatu perilaku yang telah direncanakan berhasil dilakukan, individu akan merasa puas atas hasil dari perilaku yang telah direncanakan tersebut (Diener et al., 1999). Banyak peneliti yang mengungkapkan bahwa perilaku keuangan memiliki kontribusi besar terhadap puas atau tidaknya individu atas kondisi keuangannya (Falahati et al., 2012). Perilaku keuangan berpengaruh positif terhadap kepuasan finansial (Aboagye dan Jung, 2018), (Arifin, 2018), dan (Xiao et al., 2014).

H4 : Perilaku keuangan berpengaruh signifikan terhadap kepuasan finansial pada individu yang sudah menikah di Kota Surabaya.

\section{METODE PENELITIAN}

Penelitian ini termasuk penelitian kausalitas yang bertujuan untuk mengetahui ada atau tidaknya hubungan sebab akibat antara variabel pendapatan pribadi, literasi keuangan, sikap keuangan, dan perilaku keuangan terhadap kepuasan finansial. Data primer yang yang digunakan dalam penelitian ini bersumber dari jawaban responden atas kuesioner penelitian yang disebarkan secara online dengan menggunakan teknik non probability sampling jenis purposive sampling. Individu yang sudah menikah di Kota Surabaya dengan rentang usia 25-65 tahun dan memiliki pendapatan menjadi populasi dalam penelitian ini. Dipilihnya rentang usia tersebut karena pada siklus kehidupan keuangan pada masa menikah sampai dengan masa tua atau pensiun terjadi pada usia 25-65 tahun (Ojk.go.id, 2021). Jumlah sampel ditentukan dengan menggunakan rumus dari Ferdinand (2014; 173) yang menyebutkan bahwa penentuan sampel penelitian dengan analisis regresi ditentukan dengan jumlah variabel independen dikali 25 dan untuk mengantisipasi terjadinya kesalahan dalam penyebaran kuesioner, maka ditambah $10 \%$ dari jumlah sampel. Sehingga didapatkan 110 sampel yang akan digunakan dalam penelitian.

Regresi linear berganda menggunakan program SPSS 25 dijadikan sebagai analisis data dalam penelitian ini. Melakukan uji validitas dan reliabilitas pada 35 responden terlebih dahulu untuk mengetahui keandalan data sebelum disebar secara luas sejumlah sampel. Kemudian melakukan uji normalitas, multikolinearitas, heteroskedastisitas, dan linearitas pada 110 responden sebagai syarat dapat dilakukannya uji regresi. Tahap terakhir dari analisis data yaitu melakukan uji regresi, uji t, dan koefisien determinasi.

\section{HASIL DAN PEMBAHASAN}

\section{Deskripsi Responden}

Dari 111 tanggapan responden, terdapat 1 tanggapan yang tidak sesuai dengan kriteria penelitian yang telah ditetapkan, sehingga hanya 110 tanggapan responden yang akan digunakan dalam analisis data. Responden pada usia 25-33 tahun sebanyak 30,9\%, responden pada usia 34-41 tahun sebanyak 17,3\%, responden pada usia 42-49 tahun sebanyak 18,2\%, responden pada usia 50-57 tahun sebanyak 25,5\%, dan responden pada usia 58-65 sebanyak 8,2\%. Sedangkan dilihat dari jenis kelamin, jumlah responden perempuan sebanyak 65\% dan jumlah responden laki laki sebanyak 35\%. Responden dengan pendapatan $\leq 4.200 .000$ sebanyak $40 \%$, sedangakan responden dengan pendapatan $>4.200 .000$ sampai $\leq 7.200 .000$ sebanyak $29 \%$, kemudian responden dengan pendapatan $>7.200 .000$ sampai $\leq 10.200 .000$ sebanyak $14 \%$, dan responden dengan pendapatan $>10.200 .000$ sebanyak $17 \%$. Responden domisili Surabaya Pusat sebanyak 5\%, responden domisili Surabaya Timur sebanyak $37 \%$, responden domisili Surabaya Barat sebanyak 19\%, responden domisili Surabaya Utara sebanyak $8 \%$, dan responden domisili Surabaya Selatan sebanyak $31 \%$.

\section{Analisis Data}

Uji validitas kuesioner dalam penelitian ini menggunakan analisis bivariat dengan mengkorelasikan setiap skor item pertanyaan dengan skor total. Kuesioner dikatakan valid jika nilai $r$ hitung setiap item 
lebih besar dari $r$ tabel. Berdasarkan analisis bivariat, nilai $r$ hitung dari setiap item pada variabel kepuasan finansial, literasi keuangan, sikap keuangan, dan perilaku keuangan, lebih besar dari $r$ tabel sebesar 0,3338. Dengan itu, setiap item kuesioner dikatakan valid dan dapat digunakan sebagai alat ukur dari setiap variabel dalam penelitian ini.

Untuk mengetahui konsistensi kuesioner sebagai alat ukur penelitian, dilakukan uji reliabilitas dengan menggunakan analisis reliabilitas pada SPSS. Menurut Sujarweni $(2014 ; 193)$ sebuah kuesioner dapat dikatakan konsisten jika memiliki nilai Cronbah's Alpha lebih atau sama dengan 0,60. Berdasarkan analisis reliabilitas, nilai Cronbach's Alpha pada variabel literasi keuangan sebesar 0,812, sikap keuangan sebesar 0,634 , perilaku keuangan sebesar 0;765, dan kepuasan finansial sebesar 0,805 . Nilai Cronbach's Alpha dari variabel-variabel tersebut $>0,60$, artinya kuesioner penelitian dapat dikatakan reliable atau konsisten.

Uji normalitas, uji heteroskedastisitas, uji multikolinearitas, dan uji linearitas dilakukan sebagai syarat uji regresi linear berganda. Uji Kolmogorov-Smirnov dilakukan untuk menguji normalitas data dalam penelitian ini. Dengan diperolehnya nilai Asymp. Sig. (2-tailed) sebesar 0,200>0,05 maka data dikatakan berdistribusi normal. Ada atau tidaknya heteroskedastisitas dalam penelitian ini dilihat dari nilai signifikansi uji geljser. Berdasarkan uji glejser, diperoleh nilai signifikansi variabel pendapatan pribadi sebesar 0,079, variabel literasi keuangan sebesar 0,749, variabel sikap keuangan 0,164, dan variabel perilaku keuangan sebesar 0,482. Nilai signifikansi dari keempat variabel tersebut $>0,05$, artinya data penelitian ini terhindar dari heteroskedastisitas. Dalam uji multikolinearitas, nilai VIF yang diperoleh variabel pendapatan pribadi sebesar 1,107, variabel literasi keuangan sebesar 1,711, variabel sikap keuangan sebesar 1,158 , dan variabel perilaku keuangan sebesar 1,655. Nilai VIF dari keempat variabel tersebut $>0,10$ dan $<10$, artinya data penelitian ini dikatakan bebas dari multikolinearitas. Uji linearitas dilihat dari nilai deviation from linearity sig $>0.05$. Berdasarkan uji linearitas, deviation from linearity sig dari variabel pendapatan pribadi sebesar 0,952, variabel literasi keuangan sebesar 0,261, variabel sikap keuangan sebesar 0,344, dan variabel perilaku keuangan sebesar 0,946. Nilai defiation from linearity sig dari keempat variabel tersebut $>0,05$, artinya hubungan linear antara variabel pendapatan pribadi, literasi keuangan, sikap keuangan, dan perilaku keuangan terhadap kepuasan finansial dalam penelitian ini adalah benar.

\section{Tabel 1. UJI REGRESI}

\begin{tabular}{|c|c|c|c|c|c|}
\hline \multirow{2}{*}{ Model } & \multicolumn{2}{|c|}{ Unstandardized Coefficients } & \multirow{2}{*}{$\begin{array}{c}\text { Strandardized Coefficients } \\
\text { Beta }\end{array}$} & \multirow[b]{2}{*}{$\mathbf{t}$} & \multirow{2}{*}{ Sig. } \\
\hline & B & Std. Error & & & \\
\hline (Constant) & 7,599 & 3,183 & & 2,387 & 019 \\
\hline Pendapatan &, 774 & ,243 & ,244 & 3,184 & ,002 \\
\hline SK & 180 & ,091 &, 156 & 1,986 &, 050 \\
\hline LK & 062 & 080 & ,074 &, 776 & 440 \\
\hline PK &, 547 & ,104 & ,493 & 5,256 &, 000 \\
\hline
\end{tabular}

Sumber: Output SPSS

$\mathrm{Y}=7.599+0.774 \mathrm{P}+0.062 \mathrm{LK}+0.180 \mathrm{SK}+0.547 \mathrm{PK}+\mathrm{e}$

Nilai Unstandardized B pada tabel 1 akan membentuk persamaan regresi yang ditunjukkan oleh persamaan (1). Nilai konstanta sebesar 7,599 berarti kepuasan finansial individu yang sudah menikah sebesar 7,599 apabila semua variabel konstan atau tidak memengaruhi kepuasan finansial. Koefisien regresi yang dimiliki variabel pendapatan pribadi sebesar 0,774, variabel literasi keuangan sebesar 0,062, variabel sikap keuangan sebesar 0,180, dan variabel perilaku keuangan sebesar 0,547. Kenaikan sebesar 1 satuan pada koefisien pendapatan pribadi, akan meningkatkan kepuasan finansial sebesar 0,774 kali. Kenaikan sebesar 1 satuan pada koefisien literasi keuangan, akan meningkatkan kepuasan finansial sebesar 0,062 kali. Kenaikan sebesar 1 satuan pada koefisien sikap keuangan, akan 
meningkatkan kepuasan finansial sebesar 0,180 kali, dan kenaikan sebesar 1 satuan pada koefisien perilaku keuangan, akan meningkatkan kepuasan finansial sebesar 0,547 kali.

Output SPSS uji statistik t pada tabel 1 menunjukkan berpengaruh atau tidaknya setiap variabel independen terhadap kepuasan finansial. Variabel independen dikatakan berpengaruh terhadap kepuasan finansial jika memiliki nilai $\mathrm{t}$ hitung $>\mathrm{t}$ tabel sebesar 1,983. Nilai $\mathrm{t}$ hitung variabel pendapatan pribadi sebesar 3,184, nilai t hitung variabel sikap keuangan sebesar 1,986, dan nilai $t$ hitung variabel perilaku keuangan sebesar 5,256. Ketiga variabel tersebut memiliki nilai t hitung $>1.983$, artinya pendapatan pribadi, sikap keuangan, dan perilaku keuangan berpengaruh terhadap kepuasan finansial. Sedangkan nilai t hitung pada variabel literasi keuangan sebesar 0,776 <1,983, artinya literasi keuangan tidak berpengaruh terhadap kepuasan finansial.

Tabel 2.

\section{KOEFISIEN DETERMINIASI}

\begin{tabular}{ccccc}
\hline Model & R & R Square & Adjusted R Square & Std. Error of the Estimate \\
\hline 1 &, 664 &, 441 &, 420 & 2,688 \\
\hline
\end{tabular}

Sumber: Output SPSS

Tabel 2 menunjukkan nilai Adjusted R Square sebesar 0,420 yang berarti variabel pendapatan pribadi, literasi keuangan, sikap keuangan, dan perilaku keuangan dapat menjelaskan variabel kepuasan finansial pada individu yang sudah menikah di Kota Surabaya sebesar 42\%. Terdapat $58 \%$ variabel indpenden diluar penelitian ini yang dapat menjelaskan kepuasan finansial seperti variabel financial capability, financial stressor, risk tolerance, financial solvency, debt, financial strain, dan lain-lain. Hubungan antara variabel-variabel independen tersebut terhadap kepuasan finansial ditemukan oleh Xiao et al. (2014) yang menyatakan financial capability berpengaruh positif terhadap kepuasan finansial, Halim dan Astuti (2015) yang menyatakan financial stressor, risk tolerance, dan financial solvency berpengaruh positif terhadap kepuasan finansial. Kemudian Hansen et al. (2008) menemukan debt berpengaruh negatif terhadap kepuasan finansial, dan Robb et al. (2019) menemukan financial strain memberikan pengaruh negatif terhadap kepuasan finansial.

\section{Pengaruh Pendapatan Pribadi terhadap Kepuasan Finansial}

Hasil penelitian menunjukkan pendapatan pribadi berpengaruh terhadap kepuasan finansial individu yang sudah menikah di Kota Surabaya. Selaras dengan Aboagye dan Jung (2018), Ferrer dan Gërxhani (2011), Hansen et al. (2008), Grable et al. (2013), Hakim et al. (2014), dan Sawitri (2018) yang menyatakan pendapatan pribadi berpengaruh terhadap kepuasan finansial. Jika dilihat dari usia dan jumlah pendapatan, responden usia 25-33 tahun dan responden yang memiliki pendapatan $<4.200 .000$ merupakan responden terbanyak dalam penelitian ini. Usia 25-33 merupakan usia di mana jenjang karir yang dicapai individu masih belum pada tingkatan yang tinggi dan kebutuhan untuk keluarga terutama anak masih belum tinggi. Sedangkan pendapatan $<4.200 .000$ termasuk dalam pendapatan yang rendah karena di bawah UMR Kota Surabaya. Meskipun kebanyak responden memiliki pendapatan <4.200.000 tapi masih bisa memenuhi kebutuhan dasar hidupnya karena kebutuhan pada rentang usia 25-33 tahun masih belum tinggi, sehingga kepuasan finansial masih bisa terpenuhi. Hal ini dapat dilihat dari tingginya jawaban responden akan kepuasan terhadap pendapatan yang dimilikinya saat ini dan kepuasan karena mampu memenuhi kebutuhan dasar keluarga. Arifin (2018) menyatakan kepuasan finansial berasal dari perilaku individu dalam mengelola pendapatannya guna memenuhi kebutuhan finansial, yang mana kebutuhan finansial dapat dikatakan berhasil salah satunya yaitu ketika individu dapat memenuhi kebutuhan dasarnya. Berdasarkan persamaan regresi yang terbentuk, pendapatan berkontribusi dalam meningkatkan kepuasan finansial yang paling besar, artinya kepuasan finansial individu yang sudah menikah di Kota Surabaya sangat ditentukan oleh pendapatan yang dimilikinya dapat untuk memenuhi kebutuhan dasar atau tidak. Oleh karena itu, semakin tinggi pendapatan yang diperoleh akan meningkatkan kepuasan finansial individu yang sudah menikah di Kota Surabaya. 


\section{Pengaruh Literasi Keuangan terhadap Kepuasan Finansial}

Hasil penelitian ini menunjukkan literasi keuangan tidak berpengaruh terhadap kepuasan finansial individu yang sudah menikah di Kota Surabaya. Hal ini didukung oleh Yap et al. (2016) dan Ali et al. (2013) yang menyatakan kepuasan finansial tidak dipengaruhi oleh literasi keuangan. Hal ini tidak sejalan dengan theory of planned behavior dan subjective well-being, di mana sebuah perilaku merupakan fungsi dari informasi dan dampak menyenangkan dari perilaku akan meningkatkan kepuasan individu. Berdasarkan jawaban responden, individu yang sudah menikah di Kota Surabaya memiliki pemahaman dan pengetahuan mengenai investasi dan asuransi yang tidak terlalu tinggi. Meskipun demikian, kepuasan responden akan ketersediaan uang di masa depan tinggi. Artinya, individu menikah di Kota Surabaya tidak menjadikan literasi keuangan sebagai dasar dalam keputusan dan perilaku keuangannya. Berdasarkan persamaan regresi, sikap keuangan memberikan kontribusi terhadap kepuasan finansial lebih tinggi daripada literasi keuangan. Hal ini menunjukkan bahwa kepuasan finansial individu yang sudah menikah di Kota Surabaya lebih ditentukan oleh sikap keuangan yang tinggi daripada literasi keuangan yang tinggi. Literasi keuangan yang dimiliki individu yang sudah menikah di Kota Surabaya hanya dijadikan pertimbangan dalam mengambil keputusan, namun sikap keuanganlah yang menentukan diambil atau tidaknya dan dilakukan atau tidaknya keputusan tersebut, di mana keputusan dan perilakulah yang akan menuntun individu untuk merasakan kepuasan finansial. Seperti yang dikatakan Yap et al. (2016) literasi keuangan menjadi bagian yang mendukung sikap keuangan agar seseorang berperilaku baik dalam pengelolaan keuangannya. Sikap keuangan menjadi gerbang terakhir keputusan meskipun individu tersebut benarbenar mengetahui setiap detail tentang keuangan. Pada akhirnya, kepuasan akan terwujud ketika seseorang dapat mengelola keuangannya dengan benar melalui setiap tindakan dan keputusan yang dibuatnya. Oleh karena itu, tingkat literasi keuangan yang dimiliki individu yang sudah menikah di Kota Surabaya tidak berpengeruh terhadap kepuasan finansial.

\section{Pengaruh Sikap Keuangan terhadap Kepuasan Finansial}

Hasil penelitian menunjukkan sikap keuangan berpengaruh terhadap kepuasan finansial individu yang sudah menikah di Kota Surabaya. Sejalan dengan Setiyani dan Solichatun (2019), Arifin (2018), Sawitri (2018), Falahati et al. (2012), dan Robb et al. (2019) yang menyatakan sikap keuangan berpengaruh terhadap kepuasan finansial. Berdasarkan theory of planned behavior dan subjective well-being, di mana semakin baik sikap individu maka keinginan individu dalam melakukan sesuatu semakin tinggi dan dampak menyenangkan yang dihasilkan akan meningkatkan kepuasan individu. Berdasarkan jawaban dari responden, individu yang sudah menikah di Kota Surabaya memiliki sikap keuangan dan kepuasan finansial yang tinggi. Responden memiliki sikap keuangan yang tinggi mengenai persepsi keuangan, tabungan, dan pengelolaan keuangan, di mana hal tersebut akan menimbulkan sikap-sikap keuangan yang baik seperti menabung, investasi, dan merencanakan serta mengelola keuangan di masa depan. Individu yang sudah menikah di Kota Surabaya juga memiliki kepuasan yang tinggi terhadap pendapatan, tabungan, dan pengelolaan keungan. Arifin (2018) mengatakan jika individu memiliki sikap keuangan yang baik, maka akan timbul keinginan untuk menabung, berinvestasi, dan merencanakan keuangan untuk masa depan yang lebih baik, di mana halhal tersebut akan membuat individu memiliki keuangan yang sehat sehingga dapat meningkatkan kualitas hidup dan akan meningkatkan kepuasan finansial. Oleh karena itu, sikap keuangan yang dimiliki individu yang sudah menikah di Kota Surabaya berpengaruh terhadap kepuasan finansial.

\section{Pengaruh Perilaku Keuangan terhadap Kepuasan Finansial}

Hasil penelitian menunjukkan perilaku keuangan berpengaruh terhadap kepuasan finansial individu yang sudah menikah di Kota Surabaya. Sejalan dengan Aboagye dan Jung (2018), Xiao et al. (2014), dan Sawitri (2018) yang menyatakan perilaku keungan berpengaruh positif terhadap kepuasan finansial. Berdasarkan teori subjective well-being, tercapainya tujuan individu akan meningkatkan kepuasan individu, di mana dalam mencapai tujuan tersebut tergantung pada upaya (perilaku) individu itu sendiri yang dijelaskan oleh theory of planned behavior. Berdasarkan jawaban responden, individu yang sudah menikah di Kota Surabaya memiliki perilaku keuangan yang baik. Responden melakukan perencanaan di masa depan, mengatur keuangan dengan baik sehingga dapat membayar cicilan tepat waktu, dan juga menabung untuk mempersiapkan kebutuhan masa depan. Dengan perilaku-perilaku tersebut, akan menuntun responden ke kondisi finansial yang baik dan terkontrol yang mana pada 
akhirnya akan merasakan kepuasan finansial. Terbukti dari jawaban responden yang menunjukkan individu yang sudah menikah di Kota Surabaya merasa puas akan kemampuannya dalam mengelola keuangan, puas akan adanya tabungan yang dimiliki, dan puas akan adanya ketersediaan uang untuk masa depan. Arifin (2018) mengatakan jika individu memerlakukan pendapatanya dengan hati-hati dengan mengaturnya secara teratur dan teliti serta menggunakannya dengan bijak, maka hal-hal tersebut akan membuat individu merasa puas dengan kondisi keuangannya dan menuntun individu kepada kepuasan finansial. Persamaan regresi yang terbentuk, juga menunjukkan bahwa perilaku keuanga yang dimiliki responden memiliki kontribusi terbesar kedua setelah pendapatan dalam meningkatkan kepuasan finansial. Oleh karena itu, perilaku keuangan yang dimiliki oleh individu yang sudah menikah di Kota Surabaya berpengaruh terhadap kepuasan finansial.

\section{KESIMPULAN}

Hasil penelitian menunjukkan pendapatan pribadi, sikap keuangan, dan perilaku keuangan berpengaruh terhadap kepuasan fiansial yang dirasakan individu yang sudah menikah di Kota Surabaya. Hal ini dikarenakan pendapatan pribadi responden masih dapat memenuhi kebutuhannya, penilaian responden akan keuangan yang baik membuat responden memiliki sikap-sikap keuangan yang baik (menabung, investasi, dan lain-lain), dan baiknya perilaku keuangan yang dimiliki responden membuat terkontrolnya kondisi keuangannya sesuai dengan yang diinginkan, di mana semua itu dapat meningkatkan kepuasan finansial individu yang sudah menikah di Kota Surabaya. Sedangkan variabel literasi keuangan terbukti tidak ada pengaruhnya terhadap kepuasan finansial individu yang sudah menikah di Kota Surabaya karena literasi keuangan yang dimiliki responden tidak menjadi penentu utama dalam mengambil keputusan keuangan namun sebagai bahan pertimbangan untuk mengambil keputusan, sedangkan diambil atau tidaknya keputusan ditentukan oleh sikap keuangan.

Berdasarkan temuan tersebut, diharapkan individu yang sudah menikah di Kota Surabaya memperhatikan faktor-faktor yang memengaruhi kepuasan finansial dan berusaha mencapai kepuasan finansial dengan meningkatkan pendapatan, sikap keuangan, dan perilaku keuangan sehingga mengurangi kemungkinan terjadinya pertengkaran dan perceraian akibat masalah ekonomi. Selain itu, pemerintah dan OJK juga dapat berkontribusi dalam mencegah terjadinya perceraian akibat masalah ekonomi dengan menambakan pelatihan pengelolaan keuangan yang baik di sekolah pra nikah dan memberikan konsultasi atas permasalahan finansial yang terjadi pada keuangan keluarga. Hasil penelitian ini bukanlah hasil akhir dan dimungkinkan adanya perbedaan hasil jika dilakukan penelitian ulang. Hal itu dikarenakan terdapat beberapa batasan dalam penelitian ini yaitu jumlah sampel sebesar 110 responden. Keadaan sesungguhnya dimungkinkan masih belum bisa tergambarkan dengan baik dengan 110 responden saja, sehingga penelitian selanjutnya diharapkan memperbesar jumlah sampel. Keterbatasan lainnya dalam penelitian ini yaitu hanya $42 \%$ kepuasan finansial dapat dijelaskan oleh variabel independen dalam penelitian ini, yang artinya terdapat $56 \%$ variabel independen diluar penelitian ini yang menjelaskan kepuasan finansial. Oleh karena itu, variabel financial capability, financial solvency, financial stressor, risk tolerance dan variabel independen lainnya diluar penelitian ini dapat ditambahkan dalam penelitian selanjutnya.

\section{DAFTAR PUSTAKA}

Aboagye, J., \& Jung, J. Y. (2018). Debt holding, financial behavior, and financial satisfaction. Journal of Financial Counseling and Planning, 29(2), 208-218. https://doi.org/10.1891/10523073.29.2.208

Ajzen, I. (2005). Attides, Personallity and Behavior. International Journal of Strategic Innovative Marketing, Vol. 3, p. 117.

Ali, A., Rahman, M. S. A., \& Bakar, A. (2013). FinancialLiteracyand Satisfaction in Malaysia: A Pilot Study. International Journal of Trade, Economics and Finance, 4(5), 319-324. 
Avikhatus Sholihah. Kepuasan Finansial pada Individu Menikah di Kota Surabaya

https://doi.org/10.7763/ijtef.2013.v4.309

Arifin, A. Z. (2018). Influence factors toward financial satisfaction with financial behavior as intervening variable on Jakarta area workforce. European Research Studies Journal, XXI(1), 90-103.

Azjen, I. (1991). The Theory of Planned Behavior. Organizational Behavior And Human Decision Process, 50((2)), 179-211. https://doi.org/https://doi.org/10.1016/0749-5978(91)90020-T

BPS.go.id. (2020a). Keadaan Angkatan Kerja di Indonesia Februari 2020. Retrieved March 18, 2020, from www.bps.go.id website: https://www.bps.go.id/publication/2020/06/19/c0d3df055948f7bcb65890f0/keadaan-angkatankerja-di-indonesia-februari-2020.html

BPS.go.id. (2020b). Statistik Indonesia 2020. Retrieved November 10, 2020, from www.bps.go.id website: https://www.bps.go.id/publication/2020/04/29/e9011b3155d45d70823c141f/statistikindonesia-2020.html

Chen, H., \& Volpe, R. P. (1998). An Analysis of Personal Financial Literacy Among College Students. Financial Services Review, 7(2), 107-128.

Coşkuner, S. (2016). Understanding factors affecting financial satisfaction: The influence of financial behavior, financial knowledge and demographics. Imperial Journal of Interdisciplinary Research, 2(5), 377-385.

Diener, E., Suh, E. M., Lucas, R. E., \& Smith, H. L. (1999). Subjective well-being: Three decades of progress. Psychological Bulletin, 125(2), 276-302. https://doi.org/10.1037/00332909.125.2.276

Falahati, L., Sabri, M. F., \& Paim, L. H. J. (2012). Assessment a model of financial satisfaction predictors: Examining the mediate effect of financial behaviour and financial strain. World Applied Sciences Journal, 20(2), 190-197. https://doi.org/10.5829/idosi.wasj.2012.20.02.1832

Ferdinand, A. (2014). Metode Penelitian Manajemen Pedoman Penelitian Untuk Penulisan Skripsi Tesis dan Disertasi Ilmu Manajemen. Semarang: Badan Penerbit Universitas Diponegoro.

Ferrer-i-Carbonell, A., \& Gërxhani, K. (2011). Financial Satisfaction and (in)formal Sector in a Transition Country. Social Indicators Research, 102(2), 315-331. https://doi.org/10.1007/s11205-010-9684-6

Firmansyah, T. (2020). Perceraian di Pulau Jawa Meningkat Selama Pandemi Covid-19. Retrieved November 25, 2020, from Republika.co.id website: https://republika.co.id/berita/qfrx2f377/perceraian-di-pulau-jawa-meningkat-selama-pandemicovid 19

Furnham, A. (1984). Many sides of the coin: The psychology of money usage. Personality and Individual Differences, 5(5), 501-509. https://doi.org/10.1016/0191-8869(84)90025-4

Garman, E. T., \& Forgue, R. E. (2011). Personal Finance (9th ed.). Boston: Nelson Edition.

Grable, J. E., Cupples, S., Fernatt, F., \& Anderson, N. R. (2013). Evaluating the Link Between Perceived Income Adequacy and Financial Satisfaction: A Resource Deficit Hypothesis Approach. Social Indicators Research, 114(3), 1109-1124. https://doi.org/10.1007/s11205-0120192-8 
Hakim, F. A., Sunarti, E., \& Herawati, T. (2014). Manajemen Keuangan dan Kepuasan Keuangan Istri pada Keluarga dengan Suami Istri Bekerja. Jurnal Ilmu Keluarga Dan Konsumen, 7(3), 174-182. https://doi.org/10.24156/jikk.2014.7.3.174

Halim, Y. K. E., \& Astuti, D. (2015). Financial Stressors, Financial Behavior, Risk Tolerance, Financial Solvency, Financial Knowledge, dan Kepuasan Finansial. Jurnal Finesta, 3(1), 1923.

Hansen, T., Slagsvold, B., \& Moum, T. (2008). Financial satisfaction in old age: A satisfaction paradox or a result of accumulated wealth? Social Indicators Research, 89(2), 323-347. https://doi.org/10.1007/s11205-007-9234-z

Hasibuan, B. K., Lubis, Y. M., \& HR, W. A. (2018). Financial Literacy and Financial Behavior as a Measure of Financial Satisfaction. Advances in Economics, Business and Management Research, 46(Ebic 2017), 503-507. https://doi.org/10.2991/ebic-17.2018.79

Jatim.bps.go.id. (2019). Jumlah Perceraian di Provinsi Jawa Timur Menurut Faktor dan Kabupaten/Kota 2018. Retrieved October 30, 2020, from www.Jatim.bps.go.id website: https://jatim.bps.go.id/statictable/2019/10/11/1849/jumlah-perceraian-di-provinsi-jawa-timurmenurut-faktor-dan-kabupaten-kota-2018-.html

Joo, S. (2008). Personal financial wellness. In Handbook of Consumer Finance Research. https://doi.org/10.1007/978-0-387-75734-6_2

Ojk.go.id. (2017). Strategi Nasional Literasi Keuangan Indonesia (Revisit 2017). Retrieved November 26, 2020, from www.ojk.go.id website: https://www.ojk.go.id/id/berita-dankegiatan/publikasi/Documents/Pages/Strategi-Nasional-Literasi-Keuangan-Indonesia-(Revisit2017)-/SNLKI (Revisit 2017).pdf

Ojk.go.id. (2021). Siklus Kehidupan Keuangan. Retrieved March 11, 2021, from www.ojk.go.id website: https://sikapiuangmu.ojk.go.id/FrontEnd/CMS/Category/18

Parmitasari, R. D. A. (2018). Analysis of Ethics and Investor Behavior and Its Impact on Financial Satisfaction of Capital Market Investors. Scientific Research Journal, VI(I), 51-69. Retrieved from http://www.scirj.org/jan-2018-paper.php?rp=P0118488

Robb, C. A., Chatterjee, S., Porto, N., \& Cude, B. J. (2019). The Influence of Student Loan Debt on Financial Satisfaction. Journal of Family and Economic Issues, 40(1), 51-73. https://doi.org/10.1007/s10834-018-9599-y

Rusdini, D. A., Indah, T., Mulyaningsih, S., Ghaisani, I., \& Kautsar, A. (2020). Impact of Financial Knowledge , Socio-Demographics, and Debt on Financial Satisfaction of Kediri People. International Journal of Latest Engineering and Management Research (IJLEMR), 5(1), 5.

Rutherford, L. G., \& Fox, W. S. (2010). Financial Wellness of Young Adults Age 18 - 30. Family \& Consumer Sciences Research Journal, 38(4), 468-484. https://doi.org/10.1111/j.15523934.2010.00039.x

Sawitri, N. N. (2018). Behavior in managing revenue to achieve financial satisfaction. Opcion, 34(86), 1274-1291. Retrieved from https://www.researchgate.net/publication/332263157_Behavior_in_managing_revenue_to_achi eve_financial_satisfaction

Setiyani, R., \& Solichatun, I. (2019). Financial Well-being of College Students: An Empirical Study on Mediation Effect of Financial Behavior. KnE Social Sciences, 3(11), 451-474. 
Avikhatus Sholihah. Kepuasan Finansial pada Individu Menikah di Kota Surabaya

https://doi.org/10.18502/kss.v3i11.4026

Sujarweni, V. W. (2014). Metode Penelitian: Lengkap, Praktis, dan Mudah Dipahami. Yogyakarta: Pustaka Baru Press.

Xiao, J. J., Chen, C., \& Chen, F. (2014). Consumer financial capability and financial satisfaction. Social Indicators Research, 118(1), 415-432. https://doi.org/10.1007/s11205-013-0414-8

Yap, richard josua christian, Komalasari, F., \& Hadiansah, I. (2016). the effect of financial literacy and attitude on financial management behavior and satisfaction. International Journal of Administrative Science \& Organization, 23(3), 140-146. 